\title{
気管気管支分泌液の蛋白分解酵素に関する研究
}

第 4 報 蛋白分解酵素の気管内投与によるラット分泌液中 Inhibitor の出現

*小杉 忠誠, 松尾 理, 美原 恒

**森満 保 $* * *$ 浜谷 松夫

\section{A Study on Protease in Tracheobronchial Secretion}

\section{The Occurrence of Protease Inhibitor in Tracheobronchial Secretion of Rats after the Infusion of Proteases into the Bronchus}

Tadayoshi Kosugi, M.D.. Osamu Matsuo, M.D. and Hisashi Mihara, M.D.

Department of Physiology, Miyazaki Medical College, Miyazaki

Tamotsu Morimitsu, M.D.

Department of Otorhinolaryngology, Miyazaki Medical College, Miyazaki

Matsuo Hamaya, M.D.

Department of Otorhinolaryngology, Saitama Medical College, Saitama

In previous papers, we reported that the plasminogen activator existed in the tracheobronchial secretion of normal rats, but the activities that inhibit urokinase, papain and trypsin were not found. On the other hand, it has been reported that a protease inhibitor with low molecular weight was found in the nasal secretion and tracheobronchial secretion of humans with acute inflammation of the respiratory tract. Hochstrasser et al. suggested that the protease inhibitor with low molecular weight originated from the plasma inter- $\alpha$-trypsin inhibitor and a trypsinlike enzyme in the inflammatory locus might play an important role in the production of this inhibitor. In order to examine the occurrence of protease inhibitor in the tracheobronchial secretion of rats, some proteases were infused into the tracheobronchus and the inhibitory activity on proteases was detected in the secretion.

The results obtained were as follows:

1) The occurrence of inhibitory activity on urokinase, plasmin and trypsin was not found.

2) The occurrence of inhibitory activity on papain was evident.

From the results obtained, it was concluded that the inhibitor against papain ( $\mathrm{SH}$-protease) was induced by the infusion of papain.

緒言

気道とくに下気道の急性炎症においては，気

* 宮崎医科大学生理学第 II 講座

** 宮崎医科大学耳鼻咽喉科

*** 埼玉医科大学耳鼻咽喉科
道分泌液中に蛋白分解酵素の出現あるいはその 活性上昇がみられるとの報告がなされてい $る^{122}$ ， しかしながら，この蛋白分解酵素の本 態については，現在までのところ詳細は不明で 
あるが， trypsin-like enzyme が有力視されてい る。一方, 生体においては protease-antiprotease 系ともいうべき，生体の防御機構が存在してい る。すなわち炎症の発症, 進展には, 炎症局所 あるいは体液のこれらの系のうち相対的に蛋白 分解酵素が上昇し, antiprotease 活性 (inhibi-

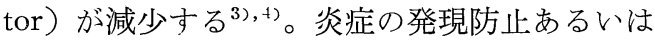
終息には，逆に相対的に inhibitor 上昇が予想 されている。Hochstrasser らの研究では，体液 中に acid stable trypsin inhibitor が存在し, この inhibitor は血中由来の inhibitor (inter$\alpha$-trypsin inhibitor) で局所において trypsinlike enzyme により低分子化されたものである ことが示されている。さらに，この inhibitor の阻害特異性は, trypsinのみではなく plasmin, chymotrypsin などに対してもみられるとの結 果を報告している5)。このような結果は，血液 中に存在する蛋白分解酵素は血中の各種の生理 的蛋白分解酵素阻害物質 ( $\alpha_{2}$-macroglobulin, $\alpha_{1}$ antitrypsin, CI inactivator, $\alpha_{2}$ PI など) にて, 2 重, 3 重に阻害されている ${ }^{6)}$ のとは対称的な 現象である。すなわち，血管外での炎症反応に より, 蛋白分解酵素活性が局所にて上昇する と, 一種類の inhibitor にても多価の inhibitor として作用する可能性がある。このような現象 は, 生体における炎症反応の制御, 統御には誠 に能率のよいものといえる。しかしながら，こ のような結果は試験管内実験から得られたもの
であり，生体内で起こり得るのかは明らかにさ れていない。そこで，我々は気道炎症での気管 気管支分泌液中の蛋白分解酵素活性の上昇を想 定し，各種の蛋白分解酵素を気管気管支内に投 与し, 採取した分泌液中に inhibitor が出現す るか否かを検討した。

\section{実験方法}

\section{(1) 実験動物}

Wistar 系ラット体重 400-600 g の雄を使用 した。

(2)蛋白分解酵素の注入と分泌液の採取方法

ウレタン麻酔下にラットの気管切開を施行 し，気管切開口部より polyethylene tube を挿 入した。ついで automatic infusion pump（ア 卜ム社製）を気管内 tube に連結し，M/15 phosphate-buffer（pH 6.8） に溶解した各種蛋白分 解酵素を気管内に注入すると同時に他方の tube より吸引し分泌液を採取した。

(3)試薬

Trypsin: Worthington Biochemical 社製 lyophilized trypsin $(238 \mathrm{U} / \mathrm{mg})$ を 用いた。

Papain：和光純薬工業製の digestive powder （1：350）を用いた。

Urokinase (UK)：持田製薬製 Uronase (6,000u）を用いた。

Plasmin：ラット血液より Plasminogenを分

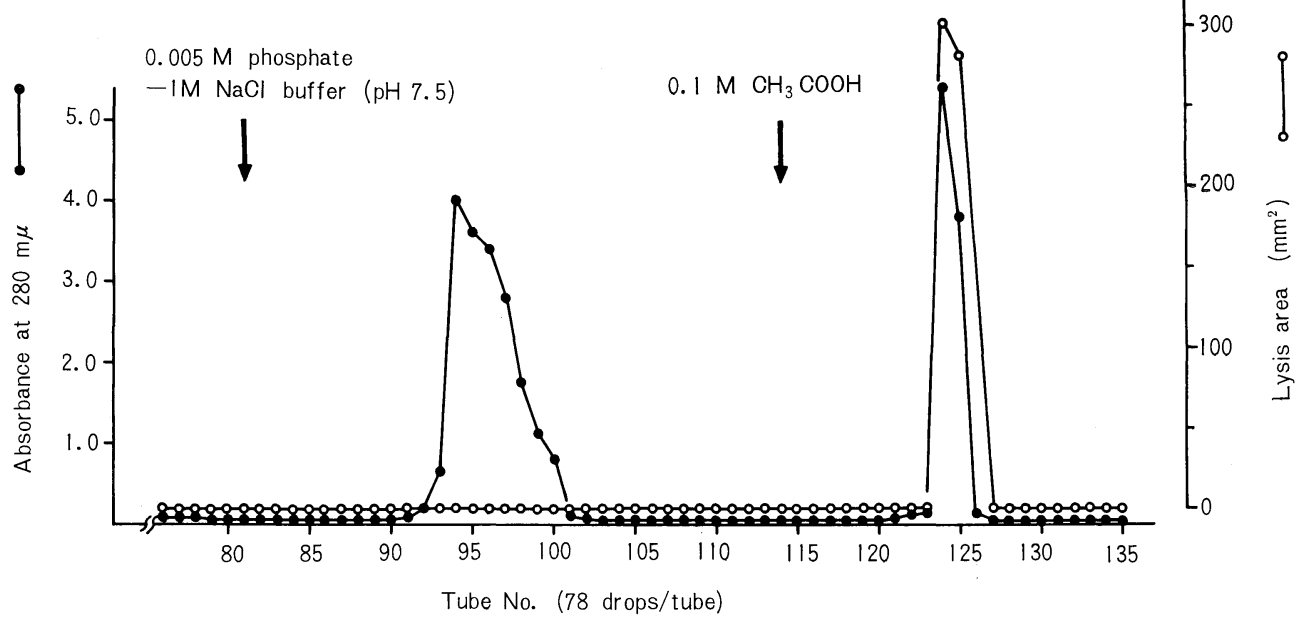

Fig. 1 Plasminogen の単離 (lysine sepharose affinity chromatography による分離, plasminogen rich fibrin plate を用いての活性測定）

$47-47$ 
離精製し，この分画にUKを问え て plasmin を作成した。その作成 方法と精製過程は実験結果の項に 述へる。

Lysine-Sepharose: 第一化学薬品製を用いた。 (4)分泌液中の蛋白分解酵素活性の測定

Trypsin $(0.1 \mathrm{mg} / \mathrm{ml})$, Papain $(10 \mathrm{mg} / \mathrm{ml})$, Plasmin (4.5casein units $/ \mathrm{ml})$, UK $(20 \mathrm{u} / \mathrm{ml})$ を気管内に注入乙，採取後の分泌液を Astrup \& Müllertz ${ }^{5}$ の方法に準じて作製した plasminogen rich fibrin plate に滴下し, $37^{\circ} \mathrm{C}, 18^{-}$ 20 時間 incubate 後, その溶解空面積を測定し た。注入した各種蛋白分解酵素活性に対する採 取後の分泌液中蛋白分解酵素との相対的変化を 調べた。

\section{実 験結果}

1）ラット plasminogen の精製と plasmin の 作製（図 1)

正常ラットより採取した血墏（3.8\%クエン 酸加）集め, これを出発材料とした。Deutsch $\&$ Mertz $^{7)}$, Matsuda $ら^{8}$ の方法に準じて, 得ら れた血漿を用いて lysine-sepharose affinity chromatography を行った。非吸着部分を採取 後, 吸着部分の溶出をまず $0.005 \mathrm{M}$ phosphate buffer-1.0M NaCl (pH 7.5) にて plasminogen

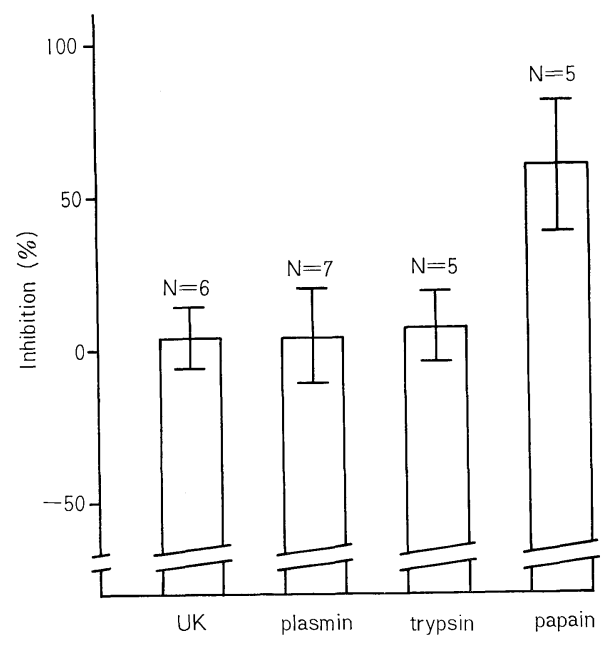

Fig. 2 分泌液中の抑制活性 activator 部分を溶出し，その後 $0.1 \mathrm{M} \mathrm{CH}_{3} \mathrm{CO}$

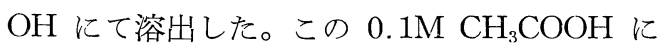
て溶出する部分を集め, 蒸留水にて充分に透析 し，その後凍結乾燥しplasminogen を作製した。 この plasminogen を M/15 phosphate-buffer （pH 6.8） に溶解し, UK $(60 \mathrm{u} / \mathrm{ml}) 0.1 \mathrm{ml}$ にて $37^{\circ} \mathrm{C}, 30$ 分 incubate し, plasmin を作製した。 この plasmin を plasminogen free fibrin plate にて溶解面皘を測定したところ，201.5 $\mathrm{mm}^{2}$ で あり plasminの標準曲線からの換算にては 4.5 casein unit $/ \mathrm{ml}$ であった ${ }^{9)}$ この plasmin 標品 を用いて以下の実験を行った。

\section{実験結果（図 2 )}

\section{1) Urokinase 注入群}

UK $(20 \mathrm{u} / \mathrm{ml})$ を注入した群では, 注入後採 取した分泌液の活性は, 注入前の活性に比して 減少率は 4.5 $\pm 10 \%$ (Mean \pm standard deviation, M.土S.D.) であった。すなわち，UK注入 後, UK に対する阻害活性の出現注認められな かった。

2) Plasmin 注入群

Plasmin (4.5 casein $\mathrm{u} / \mathrm{ml}$ ) を注入した群で は, 注入後採取した活性は, 注入前の活性に比 して減少率は $4.7 \pm 15.5 \%$ (M. \pm S.D.) であっ た。すなわち, plasmin 溶液の気管気管支内 infusion では, plasmin に対する阻害活性は分 泌液中に認められなかった。

3) Trypsin 注入群

Trypsin $(0.1 \mathrm{mg} / \mathrm{ml})$ を注入した群では, 注 入後採取した分泌液の活性は, 注入前の活性に 比して減少率は 7.5 土11.4\% (M.土S.D.) であ った。すなわち, trypsin 溶液の気管気管支内 infusion では trypsin に対する阻害活性の出現 は認められなかった。

4) Papain 注入群

Papain $(10 \mathrm{mg} / \mathrm{ml})$ を注入した群では, 注入 後採取した分泌液の活性は, 注入前の活性に比 して減少率は $60.1 \pm 21.7 \%$ (M.土S.D.) であっ た。すなわち, papain 溶液の気管気管支内 infusion では papain に対する阻害活性の出現が 認められた。

\section{総括と考按}


非炎症（正常）ラットの分泌液を採取し，試 験管内にて各種蛋白分解酵素々反応させた後の 分泌液中には，これら蛋白分解酵素を抑制する 結果は認められない事実を既に報告した。すな わち, 正常ラットの分泌液中には, fibrin を基 質としての測定では inhibitor の存在は認めら れないという結果を報告した ${ }^{103}$ 。一方, 本実験 ではラットの気管内に各種蛋白分解酵素を infusion pump を用いて注入し, 注入後得られた 分泌液中に蛋白分解酵素に対する抑制活性の出 現がみられるか否かを検討したが，papainに対 してのみ分泌液中に抑制活性が認められた。し かしながら, plasminogen activator であるUK さらには plasmin, trypsin に対しては，ほとん ど抑制活性の出現は認められなかった。Papain (SH-protease) に対する抑制物質としては, SHprotease inhibitor が知られているが，これら は組織中に存在しているとの報告がなされてい る。とくにアルサス型炎症においては，この inhibitor の出現が知られている11。今回, 我々 の実験にて認められた papain に対する抑制活 性が，上記の文献にみられる inhibitor と同一の ものであるのかは今後さらに同定実験が必要で あろら。それでは，この papain に対する抑制 物質の分泌液中への発現機序はどのようなもの であるのかを以下に考察を試みた。第一には, この papain に対する inhibitor の由来が問題と なる。血液成分の漏出により血液中 inhibitor の出現, 漏出した血液成分の proinhibitor に対 する papain による proteolytic modification の 結果としての inhibitor の出現, さらに将気管 気管支壁を構成している細胞中に存在する inhibitorの papain による分泌液中への誘導など が考慮されなければならない。今回我々が実験 に用いた papain は, thiol proteinase の一つ であり蛋白質構造の中に sulfhydral group を有 している ${ }^{12)}$ 。これらの蛋白分解酵素に対する阻 害物質としては，炎症反応にみられる中性 $\mathrm{SH}$ protease inhibitor がとくに知られている。す なわち, 組織由来の拮抗因子が知られており, 炎症の治癒局所組織の euglobulin 分画にみら れる中性 SH protease inhibitor が代表的なも のである。この捛抗物質は, ウサギ皮膚から得 られたもので分子量は10,000であり, papain
に対して抑制活性を有するが trypsin, chymotrypsin, plasmin に対しては抑制活性を有して

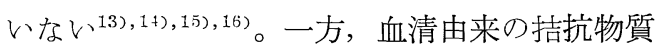
としては, ウサギ血清からのものが同定されて いる。すなわち，この血清由来の拮抗物質は多 量の糖を含む糖タンパク質であり，中性 SHprotease, papain を抑制するが trypsin, chymotrypsin を抑制しないことが知られている 以上文献的には, ウサギの炎症治療局所, お上 び血清中に papain に対する抑制物質の存在す ることが知られている。しかしながら本実験の 結果加ら，ラットにおいて血液および気管気管 支壁の構成細胞中に存在している可能性が示唆 された。一方，七ト血液中には各種の蛋白分解 酵素阻害物質が存在しており，その内 $\alpha_{2}$-macroglobulin ほ endopeptidase と結合することによ り,高分子量の基質を用いた測定法で山，それら の蛋白分解酵素の活性を抑制する作用を有して いる。Thiol proteinase $の$ papain も endope-

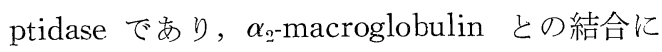
より ${ }^{18)}$ ，その抑制活性が出現した可能性も考え られる。すなわち, 気管気管支壁の血管より $\alpha_{\text {口. }}$ macroglobulin が浸出し，これと papain との 結合により papain の抑制が生じた可能性も考 慮しなければならない。とくにラット, 犬の $\alpha_{g^{-}}$ globulin はヒトの $\alpha_{\mathrm{g}}$-macroglobulin と蛋白化 学的に非常に似ていることがすでに報告されて おり ${ }^{19,20)}$, この可能性も充分に考えられる。乙 かしながら，もしこのような $\alpha_{2}$-macroglobulin の分泌液内浸出が生じているならば，他の endopeptidase すなわち serine protease である plasmin, trypsin に対しても papain と同様に 抑制活性の出現が認められるはずである。本実 験では papain に対してのみ抑制活性の出現が 認められた結果から，各種蛋白分解酵素の infusionにより分泌液中に出現する inhibitor は polyvalent teinase inhibitor である可能性が強く示唆され た。今後 papain に対する分泌液中の inhibitor の本態についての追求を課題としたい。

\section{結 論}

1）各種蛋白分解酵素の気管内投与後, 採取 した分泌液中の蛋白分解酵素に対する抑制活性 
を検討した。

2） UK, plasmin, trypsinの投与にては, 分 泌液中にこれらに対する抑制活性の出現は認め られなかった。しかしながら papain の投与に ては, 分泌液中に papain に対する抑制活性の 出現が認められた。

\section{謝辞: 本研究の一部は文部省科学研究費 (457424)} の補助を受けた。

\section{文 献}

1) Reichert, R. \& Hochstrasser, K.: Veränderungen des Proteaseninhibitorenspiegels im menschlichen Nasensekret im Verlauf verschiedener Rhinopathien. Z. Laryng. Rhinol., 51 : 73-80, 1972.

2 ) Hochstrasser, K., Schuster, R., Reichert, R. and Heimburger, N.: Nachweis und quantitative Bestimmung von Komplexen zwischen Leukozytenproteasen und $a_{1}$-Antitrypsin in Körpersekreten und Körperflüssigkeiten. Hoppe-Seyler's Z. Physoil. Chem., 323 : 1120-1124, 1972.

3 ) Jobling, J.W., Peterson, W. and Eggstein, A.: The mechanism of anaphylactic shock. J. Exp. Med., 22 : 407-417, 1965.

4) 伊崎正勝：炎症性皮膚疾患と酵素療法, 日本医 事新報, $2664: 12-18,1975$.

5 ) Hochstrasser, K., Bretzel, G., Feuth, H., Hilla, W. and Lempart, K.: The inter- $\alpha$-trypsin inhibitor as precursor of the acid stable proteinase inhibitors in human serum and urine. HoppeSeyler's Z. Physiol. Chem., 357 : 153-162, 1976.

6 ) Astrup, T. and Müllertz, S.: The fibrin plate method for estimating fibrinolytic activity. Arch. Biochem., 40 : 346-351, 1952.

7 ) Deutsch, D.G. \& Mertz, E.T.: Plasminogen, purification from human plasma by affinity chromatography. Science, 170 : 1095-1096, 1977.

8 ) Matsuda, M., Iwanaga, S., Nakamura, S.: A simple, large scale method for preparation of plasminogen-free fibrinogen, Thromb. Res., 1 : 619-630, 1972.

9 ）小杉忠誠：副鼻腔炎手術に対する抗プラスミン 剤投与の検討, 耳鼻， $22 ： 442-462,1976$.

10) 小杉忠誠, 松尾理, 美原恒, 森満保, 浜谷松夫: 気管気管支分泌液の蛋白分解酵素に関する研究, 第 3 報 ラット分泌液中のprotease-antiprotease采
の解析, 日気食会報, $30: 293-297,1979$.

11）林秀男, 樋口安典: 炎症プロテアーゼ, 炎症学 丵書 Vol. 2, edited by 安平公夫等, 医学書院, 東京, pp. 78-93 1976.

12) Mihalyi, E.: Thiol proteinases. Application of proteolytic enzymes to protein structure studies. Vol. 1. (edited. Mihalyi, E.), CRC Press, Florida, pp. $99,1978$.

13) Udaka, K.: Studies on the role of sulfhydryl groups in the biochemical mechanisms of allergic inflammation. V, Antiprotease in the cutaneous lesions of Arthus-reaction and its significance. Kumamota Med. J., 16: 70-81, 1963.

14) Udaka, K. and Hayashi, K.: Further purification of a protease inhibitor from rabbit skin with healing inflammation. Biochim. Biophys. Acta., 97 : 251-261, 1965.

15) Udaka, K. and Hayashi, K.: Molecular-weight determination of a protease inhibitor from rabbit skin with healing inflammation. Biochim. Biophys. Acta., 104 : 600-603, 1965.

16) Kambara, T., Aimoto, T. and Hayashi, H.: Incorporation of ${ }^{35} \mathrm{~s}$-methionine or ${ }^{35} \mathrm{~s}$-cystin into polypeptide protease inhibitor in the rabbit skin with healing inflammation. (preliminary report) Tohoku J. Exp. Med., 24 : 237-242, 1968.

17）佐々木実, 南方加上子, 加藤泰治, 山本紘靖, 丹羽正明：チオールプロテアーゼに特異的な血清 中のプロテアーゼインヒビター, 医用酵素, $2: 70$, 1977.

18) Heimburger, N.: Biochemistry of proteinase inhibitors from human plasma, A review of recent development. Proteinase inhibitors. (edited by Fritz, H., Tschesche, H., Greene, L.J. and Truscheit. E.), Springer-Verlag, New York, pp. 14-22, 1974.

19) Ganrot P.O.: Determination of $\alpha_{2}$-macroglobulin as trypsin-protein esterase. Clinica Chimica Acta., 14: 493-501, 1966.

20) Ohlsson, K.: Comparison of affinity of trypsin for two $\alpha_{2}$-macroglobulin fractions and for $\alpha_{1}$ antitrypsin in dog serum. Clinica Chimica Acta., $32: 215-220,1971$.

(別刷請求： ₹889-16 宮崎県宮崎郡清武町木原5200

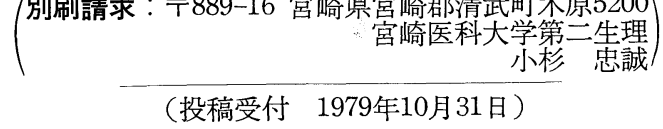

（投稿受付 1979年10月31日） 